\title{
Wet Deposition Fluxes and Related Atmospheric Chemistry at Three Sites in Mexico
}

\author{
Rosa María Cerón Bretón ${ }^{1}$, Julia Griselda Cerón Bretón1, Claudia Alejandra Aguilar Ucán1, \\ Evangelina Ramírez Lara² ${ }^{2}$, José Abraham Ortínez Álvarez ${ }^{3}$, Carlos Montalvo Romero, \\ Carmen Guadalupe Carballo Pat ${ }^{1}$ \\ ${ }^{1}$ Research Center on Environmental Sciences, Autonomous University of Carmen, Botanical Garden, \\ Carmen City, Mexico \\ ${ }^{2}$ Chemistry Department, Autonomous University of Nuevo Leon, San Nicolás de los Garza, Mexico \\ ${ }^{3}$ National Center for Training and Environmental Research, National Institute of Ecology, \\ Mexico City, Mexico \\ Email: ${ }^{*}$ rceron@pampano.unacar.mx
}

Received 7 December 2013; revised 2 January 2014; accepted 16 January 2014

Copyright @ 2014 by authors and Scientific Research Publishing Inc.

This work is licensed under the Creative Commons Attribution International License (CC BY).

http://creativecommons.org/licenses/by/4.0/

(c) () Open Access

\section{Abstract}

Wet deposition was collected in Mexico City (MC), Metropolitan Area of Monterrey (MAM) and El Chico National Park (ECNP), during 2009 and 2010. $\mathrm{pH}$, conductivity, $\mathrm{Cl}^{-}, \mathrm{SO}_{4}^{2-} \mathrm{NO}_{3}^{-}, \mathrm{NH}_{4}^{+}, \mathrm{Na}^{+}, \mathrm{K}^{+}$, $\mathrm{Ca}^{2+}$ and $\mathrm{Mg}^{2+}$ were determined. In MC, sulphate levels were greater than nitrate levels, and $\mathrm{NH} 4$ had mixed sources (vehicular emissions and agriculture activities). MAM had markedly alkaline atmospheric deposition, $\mathrm{Na}^{+}$and $\mathrm{Cl}^{-}$levels were unexpectedly high, especially during hurricane "Alex". Low pH values were found in ECNP and nitrate concentrations were high, suggesting the influence of a local source (forest fires). Deposition fluxes $\left(\mathrm{Kg}^{\left.-h a^{-1} \cdot \mathrm{yr}^{-1}\right) \text { for } \mathrm{N}-\mathrm{NO}_{3}, \mathrm{~N}-\mathrm{NH}_{4} \text { and S-SO}}\right.$ were 1.36, 2.74 and 4.84 for MAM; 7.27, 0.57 and 4.32 for ECNP; and 5.97, 4.96 and 6.78 for MC, respectively. Nitrogen deposition fluxes in ECNP were high considering that this site is a natural reserve.

\section{Keywords}

Acid Deposition; Mexican Atmospheric Deposition Network; Mexico; Wet Deposition; Wet Deposition Fluxes

${ }^{*}$ Corresponding author. 


\section{Introduction}

Deposition constitutes the final step in the removal process of trace elements from the atmosphere. Wet deposition has been monitored on a large scale across Europe and North America over the last fifteen years and has been recognised as a potential source of atmospheric inputs to terrestrial and aquatic ecosystems. In tropical countries like Mexico, where eco-tourism constitutes an important source of economic resources and where natural protected areas with great biodiversity are located near polluted cities, there is an increasing concern about the effects of atmospheric deposition on ecosystems. Although studies in other countries have investigated atmospheric deposition for several years, in Mexico, only a few studies of wet and throughfall deposition have been conducted [1]-[8], and studies on dry deposition fluxes and critical loads are scarce. Long-term, systematic and standardised data collection across the majority of tropical regions has been limited to research on the role of atmospheric deposition in tropical biogeochemical cycles [9]. Thus, critical loads and potential ecological effects of deposition in tropical environments remain uncertain; furthermore, deposition patterns and ecosystem responses may be different from those reported for temperate regions in the mid-latitudes [10]. Mexico does not have a national network to provide an outline of the main chemical characteristics of atmospheric deposition, and available data are not uniformly distributed and do not provide a solid basis for interpreting spatial variations. In response to these concerns, in 2008, the National Institute of Ecology (INE) operated the Mexican Atmospheric Deposition Network in a preliminary phase, including two urban and industrialised sites and one site within a natural protected area: Mexico City (MC), Metropolitan Area of Monterrey (MAM) and El Chico National Park (ECNP). This work studies chemical composition of wet deposition in these three sites during 2009 and 2010, discusses its sources and ecological implications.

\section{Materials and Methods}

\subsection{Sampling Sites Description}

Mexico City (MC) is considered a megacity of approximately 9 million inhabitants, Metropolitan Area of Monterrey (MAM) is an important urban and industrial region located in the northeast of the country, constituted by 12 cities or municipalities. El Chico is an important national park located in the forest region of the State of Hidalgo, covering approximately 2739 ha. The specific location and main characteristics of the sampling sites are shown in Figure 1.

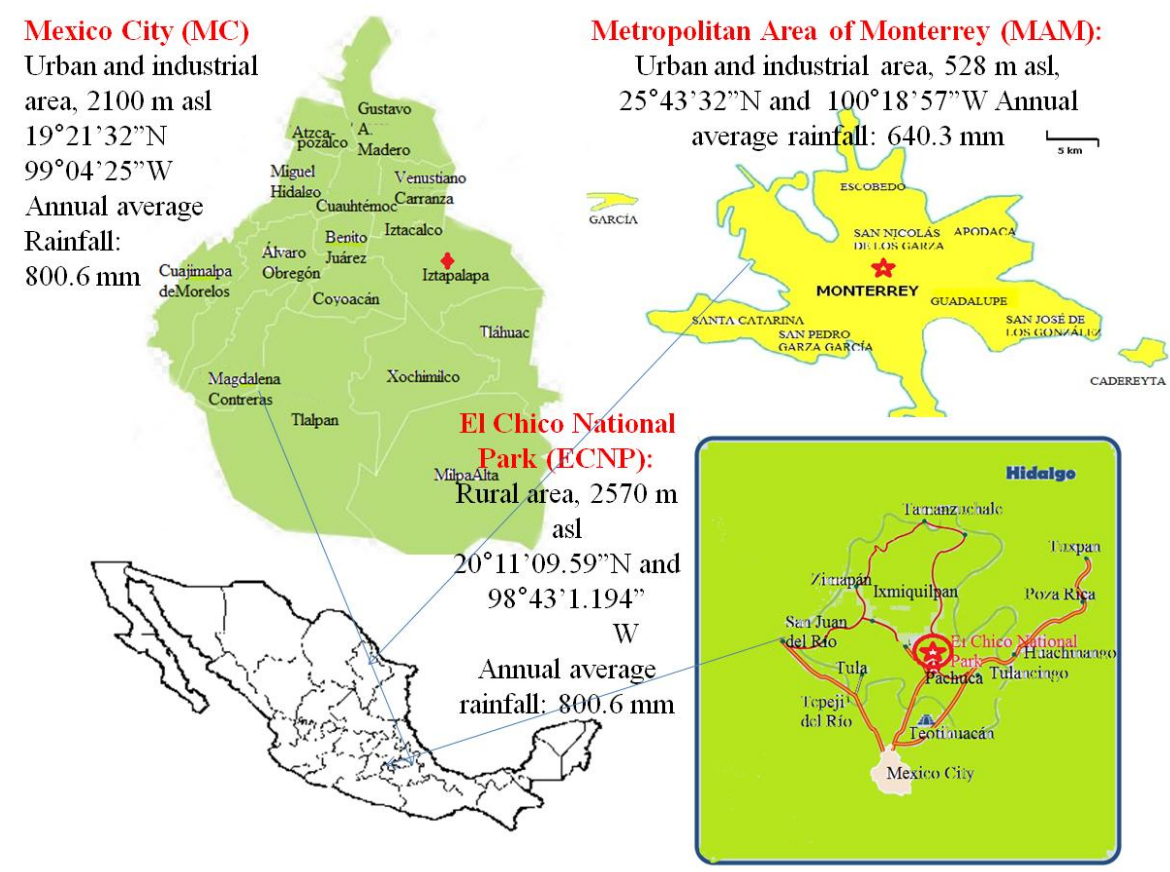

Figure 1. Location of the sampling sites. 


\subsection{Sampling Methodology and Chemical Analysis}

Wet deposition samples were collected by one automatic wet/dry deposition sampler (Tisch Environmental Inc., TE-78-100 model, USA) [11] at each site. Samples were collected on a daily basis from September 2009 to April 2010 for MC, from August 2009 to December 2009 for ECNP, and from March 2010 to July 2010 for MAM. Samples were stored at $4^{\circ} \mathrm{C}$ until analysis according to the criteria recommended by Galloway and Likens [12], assuring the stability of the samples for 6 months. Samples with a volume less than 500 ml were discarded to assure a sample volume enough for all the analytical determinations. Wet deposition fluxes for all elements were estimated considering the collection area and the sampling period. Measurements of $\mathrm{pH}$, conductivity and volume were conducted immediately on rain samples, before filtration through $0.45-\mu \mathrm{m}$ Teflon membrane filters. $\mathrm{pH}$ and conductivity measurements were obtained using a precision $\mathrm{pH}$ meter (TERMO ORION 290) and a conductivity meter (CL 135) according to EPA Methods 150.1 and 120.1, respectively [13]. $\mathrm{Cl}^{-}$, $\mathrm{SO}_{4}^{2-}$ and $\mathrm{NO}_{3}^{-}$were analysed by Ion Chromatography (Agilent 1100) using a conductivity detector (Alltech 650) with a 200- $\mu$ l sample loop according to EPA Method 300.0 modified [14]. $\mathrm{NH}_{4}^{+}$was analysed by molecular absorption spectrometry using the indophenol-blue method [15]. For cation analysis, samples were submitted to a digestion process carried out in $100 \mathrm{ml}$ Teflon closed flasks (Cole-Parmer) using autoclave equipment. $\mathrm{Na}^{+}, \mathrm{K}^{+}, \mathrm{Ca}^{2+}$ and $\mathrm{Mg}^{2+}$ were analysed by Atomic Absorption Spectroscopy (Thermoscientific ice 3000) with the Flame Technique according to EPA Methods 7770, 7610, 7140, and 7450, respectively [16]. The detection limits were calculated as three times the standard deviation of six blank samples. Repeatability was determined by analysis of samples from at least three replicate measurements. The coefficient of variation was 5\% for all of the elements. The quality of the analytical data was checked by a cation-anion balance and by comparison of measured conductivity with the conductivity calculated from the concentration of all of the measured ions and their specific conductivities.

\subsection{Meteorological Analysis}

Surface meteorological data were collected using portable meteorological stations (Davies Inc., http://www.davisnet.com.au/) operating during the entire study period. Wind roses were constructed for each site using WRPLOT VIEW 6.5.2 [17]. Air-mass backward trajectories were calculated for all days with rain events. These trajectories were used to trace the origin of the air masses for the studied period. Individual trajectories for each day were estimated $48 \mathrm{~h}$ before using HYSPLIT (Hybrid Single Particle Lagrangian Integrated) from NOAA [18]. From the calculated backward trajectories, it was observed that the prevailing winds came from the SW and NE for MC, from the SE for MAM and from the NE for ECNP.

\section{Results and Discusssion}

The annual precipitation varied markedly during 2009 and 2010. During 2009, rainfall patterns at MC were comparable to those found in ECNP. However, during 2010, the precipitation at MAM was considerably higher than at MC. MAM had unexpected rainfall in July due to the passing of Hurricane "Alex" and during September due to the influence of convective activity in the Gulf of Mexico associated with tropical storms.

Mean concentrations, $\mathrm{pH}$ and ionic abundance of the principal ions in wet deposition in MC, MAM and ECNP are shown in Table 1. Galloway et al. [19] and Casimiro et al. [20] proposed $10 \mu \mathrm{Eq} \cdot \mathrm{l}^{-1}$ and $2.8 \mu \mathrm{Eq} \cdot \mathrm{l}^{-1}$ as the most representative background hemispheric values at remote sites for sulphate and nitrate, respectively. None of the sites studied here are remote sites, so the nitrate and sulphate levels were higher than these hemispheric values for all sites (Table 1). The nitrate and sulphate levels found in MC and MAM are in agreement with those reported by other authors for these cities [1], being sulphate levels higher than nitrate. It suggests that besides local sources, mainly industrial emissions and vehicular traffic in a lesser grade (as a result of environmental policies in matter of S content reduction in fuels), regional sources contributed to the sulphate levels in rainwater in these sites. In $\mathrm{MC}$, none of the rainwater samples had $\mathrm{pH}$ values below 5.6 indicating that rain was slightly alkaline. Deposition samples in the MAM were markedly alkaline, with rainwater $\mathrm{pH}$ values ranging from 6.2 to 8.2. Since MC and MAM sites are located in the biggest cities in the country, a great variety of pollutant sources are found near each site and it is evident that mixed sources contributed to atmospheric deposition at both sites and resulted in $\mathrm{pH}$ values in the almost-alkaline range.

From Table 1, it can be observed that the $\mathrm{pH}$ values in ECNP were low, with a high percentage (92\%) of the 
Table 1. Mean values of $\mathrm{pH}$ and concentration $\left(\mu \mathrm{Eq} \cdot \mathrm{l}^{-1}\right)$ of chemical components in wet deposition samples.

\begin{tabular}{cccccc}
\hline Site & $\mathbf{p H}$ & $\mathbf{N a}^{+}$ & $\mathbf{K}^{+}$ & $\mathbf{C a}^{2+}$ & $\mathbf{M g}^{2+}$ \\
MC & 6.73 & 613.19 & 1.041 & 71.10 & 9.26 \\
MAM & 7.13 & 582.52 & 3.54 & 103.34 & 72.59 \\
ECNP & 4.71 & 142.86 & 7.58 & 46.21 & 54.95 \\
Site & $\mathbf{N H}$ & $\mathbf{C l}^{+}$ & $\mathbf{S O} \mathbf{N}_{4}^{2-}$ & 85.36 \\
MC & 267.01 & 23.96 & 124.54 & 63.73 \\
MAM & 81.29 & 56.62 & 95.98 & 266.79 \\
ECNP & 72.56 & 140.85 & 204.51 & \\
& MC Ionic abundance: & $\mathrm{SO}_{4}^{2-}>\mathrm{NO}_{3}^{-}>\mathrm{NH}_{4}^{+}>\mathrm{Ca}^{2+}>\mathrm{Cl}^{-}>\mathrm{Na}^{+}>\mathrm{Mg}^{2+}>\mathrm{K}^{+}$ \\
& MAM Ionic abundance: & $\mathrm{SO}_{4}^{2-}>\mathrm{NO}_{3}^{-}>\mathrm{Ca}^{2+}>\mathrm{Cl}^{-}>\mathrm{Na}^{+}>\mathrm{NH}_{4}^{+}>\mathrm{Mg}^{2+}>\mathrm{K}^{+}$ \\
& ECNP Ionic abundance: & $\mathrm{NO}_{3}^{-}>\mathrm{SO}_{4}^{2-}>\mathrm{Na}^{+}>\mathrm{Cl}^{-}>\mathrm{NH}_{4}^{+}>\mathrm{Mg}^{2+}>\mathrm{Ca}^{2+}>\mathrm{K}^{+}$ \\
\hline
\end{tabular}

rain samples below pH 5.6. Additionally, nitrate concentrations were greater than sulphate levels and were even higher than those reported for polluted sites such as Mexico City. At the beginning of this study, the ECNP site was treated as a control site; it was an interesting discovery that this site was potentially impacted by the high deposition rate of $\mathrm{N}$; this can be a significant problem for sacred fir forests (the dominant vegetation at this site). Data obtained and forestry research carried out at this specific site provided evidence that forest fires occur frequently and directly influence the natural reforestation dynamic of the sacred fir forests [21] [22]. During 2009, Hidalgo State registered a high occurrence of forest fires (311) [23]. Satellite images were consulted for the studied period from the Hazard Mapping System Fire and Smoke Products (NOAA NESDIS HMS) [24] in order to identify days with fire occurrence. Some images were not available (for November 2009), however, from the available information, a direct relationship was observed between days with fire occurrence and rainwater samples with high nitrate levels and low $\mathrm{pH}$ values, suggesting that forest fires were the local source of nitrates in this site (Figure 2).

Although ECNP is an important natural area in the country, it cannot be considered remote because it is located at 20, 70 and $120 \mathrm{~km}$ from the industrialised cities of Pachuca, Tula and Mexico, respectively. Consequently, this site receives both local emissions as well as inputs of pollutants subjected to transport processes, resulting in $\mathrm{pH}$ values and acid precursor gases concentrations that are different from those expected for natural sites. Clearly, a local source was strongly influencing nitrate and $\mathrm{pH}$ levels. $\mathrm{Na}^{+}$and $\mathrm{Cl}^{-}$concentrations found in wet deposition for ECNP were high. Several authors have reported that during forest fires also there is an important primarily emission of $\mathrm{K}^{+}, \mathrm{Ca}^{2+}, \mathrm{NO}_{3}^{-}, \mathrm{SO}_{4}^{2-}, \mathrm{NH}_{4}^{+}, \mathrm{Cl}^{-}$and $\mathrm{Na}^{+}$[25]-[27]. Since, ECNP is not a coastal site, it could explain the relatively high concentrations for $\mathrm{Na}^{+}$and $\mathrm{Cl}^{-}$found.

Ammonium levels found in MC were quite high and probably had their origin in the following sources: industrial plants, livestock farming, use of fertilisers in surrounding agricultural areas and vehicular emissions. According to the emissions inventory for Metropolitan Area of Mexico Valley (MAMV) in 2010 [28], industrial sources, livestock farming, agriculture activities and mobile sources (mainly light duty vehicles) contributed 72.67\%, $11.5 \%, 5.2 \%$ and $10.63 \%$ to the total $\mathrm{NH}_{3}$ emissions $\left(41,845 \mathrm{t} \cdot \mathrm{yr}^{-1}\right)$, respectively. The sampling site in MC is located in Iztapalapa District, at the southeast edge of the city, adjacent to the rural areas of Mexico State. The prevailing wind direction in this site came from NE, where agriculture constitutes the main activity (Municipalities of Chicoloapan and Chimalhuacán), and the use of fertilisers could explain the ammonium levels that were found. On the other hand, regarding $\mathrm{NH}_{3}$ emissions from mobile sources, Bishop et al. [29] and Huai et al. [30] reported that $\mathrm{NH}_{3}$ formation can be attributed primarily to reactions that occur within the catalytic converters, age and operating conditions of the vehicle which play an important role in the formation of $\mathrm{NH}_{3}$ in exhaust. It has been found that newest vehicles (15 years or less) usually have higher production rates, after this peak, the levels begin to decline with age (as the catalytic converters age, they begin to lose their reducing capacity and production rates decrease). Emissions inventory for MAMV in 2010 [28] reports that there were 4, 787, 077 light duty vehicles registered (84\% corresponded to a vehicular fleet with an age between 1 and 15 years). 


\section{$\mathrm{NO}_{3}$ concentrations, pH values and forest fires occurrence ECNP 2009}

Specific date for Forest fires events are showed in red labels

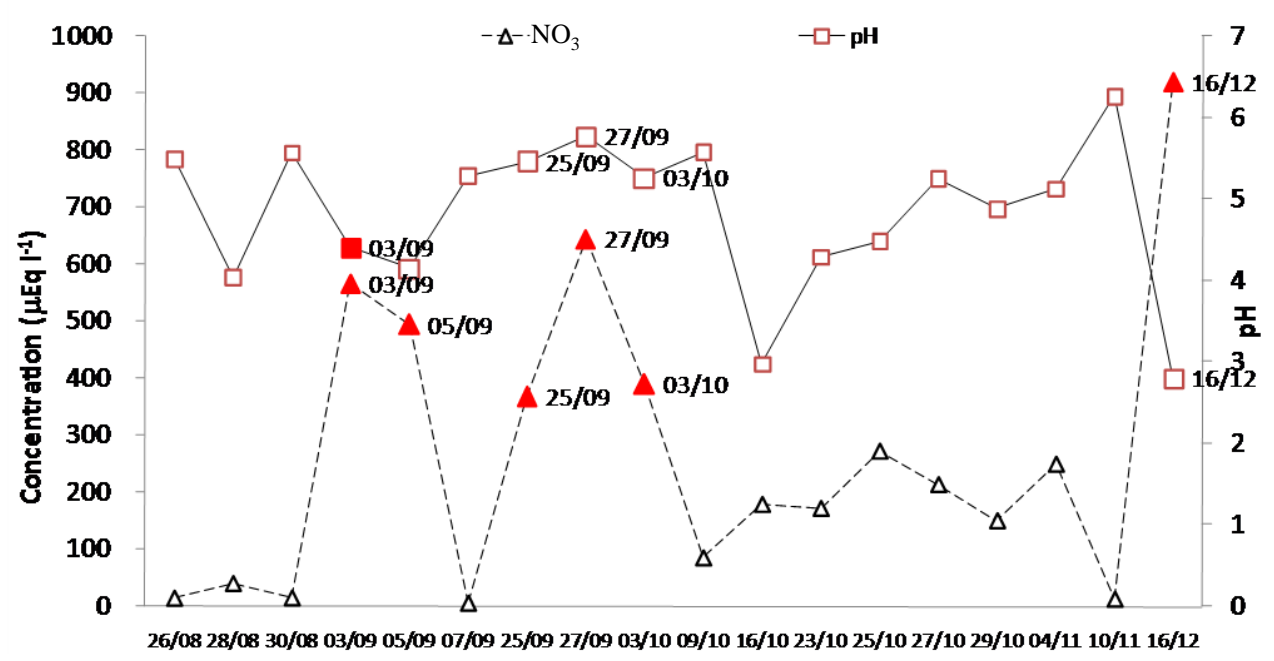

Figure 2. Relation among $\mathrm{NO}_{3}$-concentrations, $\mathrm{pH}$ values and forest fire occurrence for ECNP.

In MAM, calcium levels were high, suggesting a significant contribution from sources of crustal material; this was expected because calcisols are the dominant soil type in the Monterrey area. Sodium and chloride levels in MAM were high, Some samples were taken before, during and after the passage of Hurricane "Alex" through Monterrey at the end of June and the beginning of July 2010. Monahan [31] found an abrupt increase of sea spray droplets when wind speed increases as hurricanes approach the coast; this was also observed by Lindner and Frysinger [32] and Padilla et al. [3]. This could explain the unexpectedly high levels of sodium and chloride considering that Monterrey is not a coastal site. This behaviour can be due to this city is frequently subjected to maritime air masses from the Gulf of Mexico during the summer season. Mean nitrate and sulphate values obtained in MC were typical from a megacity. $\mathrm{SO}_{4}^{2-}$ and $\mathrm{NO}_{3}^{-}$levels in MAM are comparable to those obtained in MC. This is evidence that MAM (the third largest city in Mexico) can be considered as a megacity too, because of the high fuel consumption from the urbanization and industrialization, and the rapid increase in the vehicular fleet result in high emissions of $\mathrm{SO}_{2}$ and $\mathrm{NO}_{\mathrm{x}}$, forming high concentrations of acids in this region. Finally, sulphate and nitrate levels in ECNP were influenced by both, local and regional emissions, being local contributions more significant than regional.

For MC and MAM, despite high quantities of $\mathrm{SO}_{4}^{2-}$ and $\mathrm{NO}_{3}^{-}$found in rainwater samples, the contribution of alkaline constituents was evident. This was not the case for ECNP. The mean $\mathrm{SO}_{4}^{2-}$ concentrations in rainwater samples in MC and MAM were higher than $\mathrm{NO}_{3}^{-}$, this suggests that there were contributions from both local and regional sources of sulphate, whereas for $\mathrm{NO}_{3}^{-}$, the influence of local sources was evident. The $\mathrm{SO}_{4}^{2-} /$ $\mathrm{NO}_{3}^{-}$ratio is a good marker to indicate the prevalence of acidifying species other than $\mathrm{NO}_{3}^{-}$[33]. In this study, these ratios were calculated from individual data values. $\mathrm{SO}_{4}^{2-} / \mathrm{NO}_{3}^{-}$ratio for $\mathrm{MC}$ was close to unity (1.13), suggesting that both ions contributed to the acidity. On the other hand, $\mathrm{SO}_{4}^{2-}$ contributed to the majority of the acidity for wet deposition samples in MAM, ( $\mathrm{SO}_{4}^{2-} / \mathrm{NO}_{3}^{-}$ratio equal to 3.54). $\mathrm{NO}_{3}^{-}$levels were higher than $\mathrm{SO}_{4}^{2-}$ in ECNP and $\mathrm{SO}_{4}^{2-} / \mathrm{NO}_{3}^{-}$ratio was very low. The $\mathrm{NO}_{3}^{-}$ions prevailed among other acidifying species, this fact can be attributed to local emissions from forest fires occurring during the sampling period.

To verify which cation neutralised the acidic components more frequently in wet deposition, neutralisation factors (NF) were estimated. $\mathrm{NH}_{4}^{+}$was the major ion contributing to neutralisation in wet deposition at $\mathrm{MC}$, suggesting that the influence of local mobile sources (considering that $84 \%$ of vehicular fleet corresponds to light duty vehicles) and rural zones (mainly agricultural) of Mexico State via NE winds was significant.

$\mathrm{Ca}^{2+}$ and $\mathrm{Na}^{+}$played important roles in the neutralisation process in wet deposition in MAM; this can be explained from the crustal composition in the surroundings of this site, where calcisols are the dominant soil type. 
The presence of high quantities of sodium during the passage of Hurricane "Alex" and as a result of the input of maritime air during the summer seems to be also important in the neutralisation process, resulting in slightly alkaline $\mathrm{pH}$ values.

Finally, in ECNP, $\mathrm{Ca}^{2+}$ was the most important ion in the neutralisation process in the wet deposition. This suggests that a mixed source emitting alkaline particles contributed to this process; this is expected because ECNP constitutes a complex mosaic of forested, agricultural and rural ecosystems with diverse land-use histories and also includes the influence of regional anthropogenic sources as a result of transport process and the influence of local emissions from the frequent forest fires occurring during the sampling period.

The origin of elements in atmospheric deposition samples can be inferred by correlations between elements, thus allowing the identification of common sources of atmospheric species, similar removal processes or strong acid-base relations. Pearson's correlation analysis $(p=0.001)$ was applied to test the relationship among ionic concentrations for each sampling site. The pattern of ion correlation in rainwater samples was similar for MC and MAM, which is expected considering the similar emissions sources for both urbanized areas.

In $\mathrm{MC}, \mathrm{SO}_{4}^{2-}$ and $\mathrm{NO}_{3}^{-}$were correlated, suggesting a common source. In addition, $\mathrm{NH}_{4}^{+}-\mathrm{SO}_{4}^{2-}$ and $\mathrm{NO}_{3}^{-}$ - $\mathrm{NH}_{4}^{+}$were significantly correlated, providing evidence of a strong acid-base relationship between these ion pairs and suggesting that these ions were deposited as ammonium sulphate and nitrate formed by gas-phase reactions of ammonia with sulphuric and nitric acids. During 2010, in MAM, the influence of Hurricane "Alex" at the end of June and the beginning of July was quite evident from the high correlation coefficient between $\mathrm{Na}^{+}$ and $\mathrm{Cl}^{-}$. This behaviour was also observed at a lesser scale during the rest of the sampling period, suggesting that MAM is influenced by marine aerosols during the summer season, when prevailing easterlies increase the input of maritime air toward this area. However, this behaviour was not observed for other ions commonly present in marine aerosol such as $\mathrm{SO}_{4}^{2-}$ and $\mathrm{Mg}^{2+}$. $\mathrm{Ca}^{2+}$ and $\mathrm{Mg}^{2+}$ correlated significantly, suggesting that these ions had the same source, such as soil particles and marine aerosol. Additionally, $\mathrm{SO}_{4}^{2-}$ and $\mathrm{NO}_{3}^{-}$were highly correlated, suggesting that these ions originated from common sources, probably combustion processes. This assumption is supported by the high levels of acidifying species and the almost alkaline $\mathrm{pH}$ values, as a result of a strong acid-base relationship between nitrate and sulphate (coming from both local and regional sources) and basic species originating from local sources. A close correlation between $\mathrm{NO}_{3}^{-}, \mathrm{SO}_{4}^{2-}$ and $\mathrm{NH}_{4}^{+}$was also found, suggesting the importance of ammonium in the neutralisation process. In the case of ECNP, a high correlation between $\mathrm{Ca}^{2+}$ and $\mathrm{K}^{+}$was observed, indicating that these ions were derived from crustal contributions. Notably, correlation between $\mathrm{SO}_{4}^{2-}$ and $\mathrm{NO}_{3}^{-}$, was negligible, suggesting that these ions did not originate from the same source. This supports the notion that $\mathrm{NO}_{3}^{-}$originated from a local source, probably forest fires, whereas $\mathrm{SO}_{4}^{2-}$ probably was transported from regional sources.

From Figure 3, it can be observed that estimated wet deposition fluxes had a high variability among sites. These differences are expected because the annual average precipitation reported for each site was very different; whereas MC and ECNP were characterized by abundant rainfall, in MAM, prevailing anti-cyclonic systems for most of the year resulted in scarce rains, excepting during the Alex hurricane event.

Wet deposition fluxes for MC during 2010 were not considered because the sampling period did not include the whole rainy season. These results indicate that wet deposition in the studied sites was influenced by both, local and regional sources. However, this study did not estimate the relative contribution of each one of these sources. In MAM the highest fluxes were for $\mathrm{S}_{-} \mathrm{SO}_{4}^{2-}$ and $\mathrm{Cl}^{-}$, whereas $\mathrm{S}-\mathrm{SO}_{4}^{2-}$ and N- $\mathrm{NO}_{3}^{-}$had the highest fluxes in MC and ECNP. Background wet deposition rates for remote tropical areas reported for $\mathrm{S}$ and $\mathrm{N}$ are 1 -

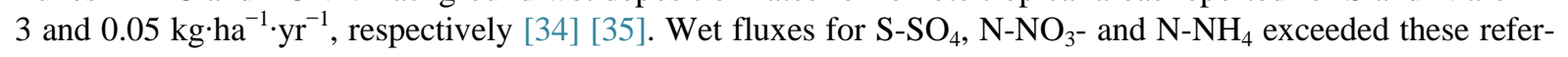
ence values in all the studied sites.

Fenn et al. (2002) made an historical revision of sulphate: nitrate ratios in wet and throughfall deposition in the Mexico City Air Basin during 1980's and 1990's. They found sulphate: nitrate ratios of 1.8 for Desierto de los Leones and 2.7 for Zoquiapan, located at SW and SE, respectively during 1990's. Studies carried out during 1980's [36] reported an average sulphate: nitrate ratio of 3.9 for urban sites in Mexico City. In this study it was found a sulphate: nitrate deposition ratio of 1.13 for a site located at the SE of Mexico City. This fact suggests a downward trend in atmospheric $\mathrm{SO}_{2}$ concentrations in Mexico City in the last years as a result of the use of cleaner fuels since 2005 with a reduced S content (diesel with a maximum S content of $0.05 \%$ and gasoline ultra-reduced in S with a maximum S content from 30 to $80 \mathrm{ppm}$ for new vehicles) [36]. For ECNP and MAM, this ratio was of 0.59 and 3.55 , respectively; however there are not available similar historical data for these sites. 


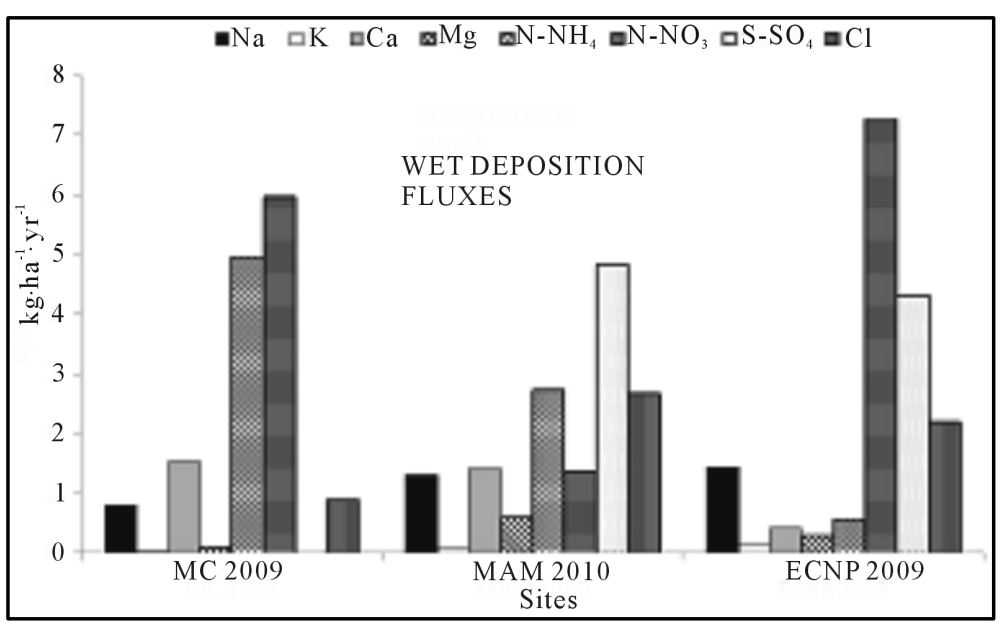

Figure 3. Wet atmospheric deposition fluxes for MC (September-December 2009), MAM (March-July 2010) and ECNP (August-December 2009).

On the other hand, these results suggest that nitrate concentrations in precipitation have been increased due to an increase in the vehicular fleet of 36\% in the last ten years. Fenn et al. [5] reported annual fluxes in throughfall deposition for $\mathrm{N}$ and S at Desierto de Los Leones of 18.5 and $20.4 \mathrm{~kg} \cdot \mathrm{ha}^{-1} \cdot \mathrm{yr}^{-1}$, respectively. Nitrogen and Sulphur fluxes in wet deposition found in this study in MC (5.97 and $\left.6.78 \mathrm{~kg} \cdot \mathrm{ha}^{-1} \cdot \mathrm{yr}^{-1}\right)$ were close to those found by Fenn et al. [5] in throughfall deposition in Zoquiapan (5.5 and $8.8 \mathrm{~kg} \cdot \mathrm{ha}^{-1} \cdot \mathrm{yr}^{-1}$, respectively), a site located at SE of the Mexico City.

\section{Conclusions}

The study of wet deposition at three different sites in Mexico provided an outline of the chemical characteristics and removal processes of deposited pollutants. Nitrate and sulphate levels in wet deposition samples from Mexico City (MC) and Metropolitan Area of Monterrey (MAM) were comparable, and $\mathrm{SO}_{4}^{2-}$ concentrations were higher than those for $\mathrm{NO}_{3}^{-}$, suggesting that urban and industrial sources (regional and local) influenced the rainwater chemistry. $\mathrm{pH}$ values in both $\mathrm{MC}$ and MAM were almost alkaline, indicating that a great variety of mixed sources contributed to atmospheric deposition in these cities, with emissions of acid rain precursors from industrial sources and alkaline components from different sources (crustal, agricultural activities and vehicles with three-way catalytic converters). Nitrate and sulphate levels were strongly correlated, indicating that these ions had a common source.

In contrast, nitrate levels in El Chico National Park (ECNP) were high, and pH values were in the acidic range. Furthermore, $\mathrm{SO}_{4}^{2-}$ did not correlate with $\mathrm{NO}_{3}^{-}$suggesting that they originated from different sources. Nitrate levels were higher than sulphate levels, indicating that local sources contributed a great proportion of the acidity, including forest fires and controlled fires (used as a forestry management strategy in sacred fir forests) that occurred during the sampling period.

$\mathrm{Na}^{+}$and $\mathrm{Cl}^{-}$levels in the MAM were high as a result of the passage of Hurricane "Alex", but these relatively high levels prevailed even after Hurricane "Alex", suggesting that in addition, MAM was exposed to maritime air masses from the Gulf of Mexico during the summer season. This is consistent with the prevailing winds blowing from southeast during the entire study.

Since data were collected in a short time frame, seasonal and temporal trends were not observed in any of the three study sites; however the behaviour of $\mathrm{NO}_{3}^{-}, \mathrm{SO}_{4}^{2-}$ and $\mathrm{NH}_{4}^{+}$was similar for all sites, providing evidence of a contribution from industrial and vehicular sources, as well as a strong acid-base relationship between these components. Estimated wet deposition fluxes varied greatly among the sites.

Finally, nitrate and sulphate levels in ECNP were high compared to background hemispheric values reported for remote sites. ECNP is a complex site due to the influenced of local and regional emissions. As discussed in Section 3.2, forest fires influenced nitrate levels and $\mathrm{pH}$ values. Therefore, this site is potentially impacted by $\mathrm{N}$ deposition.

Specific critical loads in Mexico are scarce and the majority of the studies have been carried out in Mexico 
Valley, mainly in pine forest located at Desierto de los Leones and Ajusco National Park [5] [37]. Therefore, in order to estimate the potential effects of atmospheric deposition on sensitive ecosystems in these sites, it is necessary to propose critical loads for water, soil and vegetation, and then, to determine if these critical loads values are currently exceeded.

\section{Acknowledgements}

This work was financially co-supported by The Mexican Sectorial Fund CONACYT-SEMARNAT (project 107948) and by National Institute of Ecology (projects INE/A1-047/2008, INE/A1-007/2009, INE/A1-031/ 2010). The authors gratefully acknowledge the help from students that supported during this work: Yuliana del Carmen Chablé Herrera, Laura Tecuautzín Ramírez, Berenice Díaz Morales and Carmen Guadalupe Carballo Pat.

\section{References}

[1] Báez, A.P., Padilla, H.G., Cervantes, J., Pereyra, D. and Belmont, R. (1997) Rainwater Chemistry at the Eastern Flanks of the Sierra Madre oriental, Veracruz, Mexico. Journal of Geophysical Research, 102, 23329-23336. http://dx.doi.org/10.1029/97JD02077

[2] Fenn, M.E., de Bauer, L.I., Quevedo-Nolasco, A. and Rodriguez Fraustro, C. (1999) Nitrogen and Sulfur Deposition and Forest Nutrient Status in the Valley of Mexico. Water, Air and Soil Pollution, 113, 155-174. http://dx.doi.org/10.1023/A:1005033008277

[3] Padilla, H.G., Belmont, R., Torres, M.B. and Báez, A.P. (2000) Hurricanes Pauline and Nora Rainwater Chemical Composition. Canadian Journal of Earth Sciences, 37, 569-578. http://dx.doi.org/10.1139/e99-114

[4] Cerón, R.M.B., Padilla, H.G., Belmont, R., Torres, M.C.B., García, R.M. and Báez, A.P. (2002) Rainwater Chemical Composition at the End of the Mid-Summer Drought in the Caribbean Shore of the Yucatan Peninsula. Atmospheric Environment, 36, 2367-2374. http://dx.doi.org/10.1016/S1352-2310(02)00169-3

[5] Fenn, M.E., De Bauer, L.I. and Hernandez-Tejeda, T. (2002) Summary of Air Pollution Impacts on Forest in the Mexico City Air Basin. In: Fenn, M.E., Bauer, L.I. and Hernandez-Tejeda, T., Eds., Urban Air Pollution and Forests: Resources at Risk in the Mexico City Air Basin, Ecological Studies Series, Vol. 156, Springer-Verlag, New York, 337355. http://dx.doi.org/10.1007/978-0-387-22520-3_15

[6] Pérez-Suárez, M., Fenn, M.E., Cetina-Alcalá, V.M. and Alderete, A. (2008) The Effects of Canopy Cover on Throughfall and Soil Chemistry in Two Forest Sites in the Mexico City Air Basin. Atmósfera, 21, 83-100.

[7] Cerón, R.M., Cerón, J.G., Guerra, J.J., Núñez, E. and Muriel, M. (2010) Contribution of Anthropogenic and Natural Sources to the Levels of Trace Elements in Two Coastal Sites in Campeche, Mexico. International Journal of Sustainable Development and Planning, 5, 282-298. http://dx.doi.org/10.2495/SDP-V5-N3-282-298

[8] Ponette-Gonzalez, A.G., Weathers, K.C. and Curran, L.M. (2010) Tropical Land-Cover Change Alters Biogeochemical Inputs to Ecosystems in a Mexican Montane Landscape. Ecological Applications, 20, 1820-1837. http://dx.doi.org/10.1890/09-1125.1

[9] Rodhe, H. and Herrera, R. (1988) Acidification in Tropical Countries. 1st Edition, John Wiley \& Sons Ltd., New York.

[10] Tanner, E.V.J., Vitousek, P.M. and Cuevas, E. (1998) Experimental Investigation of Nutrient Limitations of Forest Growth on Wet Tropical Mountains. Ecology, 79, 10-22. http://dx.doi.org/10.1890/0012-9658(1998)079[0010:EIONLO]2.0.CO;2

[11] Tisch Environmental (2013) Global Distribution and Manufacturing of Environmental Monitoring Instruments. www.tisch-env.com

[12] Galloway, J.N. and Likens, G.E. (1976) Calibration of Collection Procedures for the Determination of Precipitation Chemistry. Water, Air and Soil Pollution, 6, 241-258. http://dx.doi.org/10.1007/BF00182868

[13] US EPA, Methods 150.1, 1201.1 (1982) Methods for Chemical Analysis of Water and Wastes. US Environmental Protection Agency.

[14] US EPA, Method 300.0 (1993) Anions. US Environmental Protection Agency, Office of Research and Development, Nitrate, Sulphate and Chloride by IC, 600/4-79-020 Report.

[15] APHA-AWWA-WPCF (1989) Ammonium in Wet Deposition/Automated Colorimetric. 600-86-024 Report.

[16] US EPA, Methods 7770, 7610, 7140,7450 (1986) Methods for Chemical Analysis of Water and Wastes. US Environmental Protection Agency: Sodium-AA, Direct Aspiration SW-846 Chapter 3.3; Potassium-AA, Direct Aspiration SW846 Chapter 3.3; Calcium-AA, Direct Aspiration SW-846 Chapter 3.3; Magnesium-AA, Direct Aspiration SW-846 Chapter 3.3, Office of Research and Development. 
[17] Lakes Environmental, Inc. (2011) Lakes Environmental Software. WRPLOT View v.6.5.2. Freeware Wind Rose Plots for Meteorological Data. http://www.weblakes.com/products/wrplot/index.html

[18] Draxler, R.R. and Hess, G.D. (1997) Description of the HYSPLIT_4 Modeling System. NOAA. Tech. Memo. ERL ARL-224, NOAA Air Resources Laboratory, Silver Spring, 1-24.

[19] Galloway, J.N., Likens, G.E., Keene, W.C. and Miller, J.M. (1982) The Composition of Precipitation in Remote Areas of the World. Journal of Geophysical Research, 87, 8771-8776. http://dx.doi.org/10.1029/JC087iC11p08771

[20] Casimiro, A.P., Salgueiro, M.L. and Nunes, V.T. (1991) Seasonal and Air-Mass Trajectory Effects on Rainwater Quality at the South-Western European Border. Atmospheric Environment, 25, 2259-2266. http://dx.doi.org/10.1016/0960-1686(91)90101-C

[21] Ikkonen, E., Angeles-Cervantes, E.R. and García-Calderón, N. (2004) Producción de $\mathrm{CO}_{2}$ en Andosoles Afectados por Incendios Forestales en el Parque Nacional El Chico, Hidalgo. Terra Latinoamericana, 22, 425-431.

[22] Angeles, E.R. (2010) Efectos Ecológicos de los Incendios Forestales Sobre el Bosque de Oyamel. Ph.D. Dissertation, Colegio de Postgraduados Campus Montecillo, Postgrado de Botánica.

[23] CONAFOR-SEMARNAT (2009) Final Report of Forest Fires 2009. Weekly Report of results of Forest Fires, Protection Agency against Forest Fires, National Forest Commission-Environmental Mexican Agency.

[24] NOAA NESDIS HMS (2009) Hazard Mapping System Fire and Smoke Product. US National Oceanic and Atmospheric Administration, National Environmental Satellite Data and Information Service. http://www.osdpd.noaa.gov/ml/land/hms.html

[25] Sanhueza, E. and Rondon, A. (1988) Particle-Size Distribution of Inorganic Water Soluble Ions in the Venezuelan Savannah Atmosphere during Burning and Nonburning Periods. Journal of Atmospheric Chemistry, 7, 369-388. http://dx.doi.org/10.1007/BF00058711

[26] Echalar, F., Gaudichet, A., Cachier, H. and Artaxo, P. (1995) Aerosol Emissions by Tropical Forest and Savannah Biomass Burning: Characteristic Trace Elements and Fluxes. Geophysical Research Letters, 22, 3039-3042. http://dx.doi.org/10.1029/95GL03170

[27] Yamasoe, M.A., Artaxo, P., Miguel, A.H. and Allen, A.G. (2000) Chemical Composition of Aerosol Particles from Direct Emissions of Vegetation Fires in the Amazon Basin: Water-Soluble Species and Trace Elements. Atmospheric Environment, 34, 1641-1653. http://dx.doi.org/10.1016/S1352-2310(99)00329-5

[28] SIMA (2012) Federal District Government. Emissions Inventory for the Metropolitan Zone of Mexico Valley. Atmospheric Monitoring System, First Edition, Mexican Environmental Agency. www.sma.df.gob.mx/inventario_emisiones/

[29] Bishop, G.A., Peddle, A.M. and Stedman, D.H. (2010) On-Road Emission Measurements of Reactive Nitrogen Compounds from Three California Cities. Environmental Science and Technology, 44, 3616-3620. http://dx.doi.org/10.1021/es903722p

[30] Huai, T., Durbin, T.D., Miller, J.W., Pisano, J.T., Sauer, C.G., Rhee, S.H. and Norbeck, J.M. (2003) Investigation of $\mathrm{NH}_{3}$ Emissions from New Technology Vehicles as a Function of Vehicle Operating Conditions. Environmental Science and Technology, 40, 7018-7022.

[31] Monahan, E.C. (1968) Sea Spray as a Function of Low Elevation Wind Speed. Journal of Geophysical Research, 73, 1127-1137. http://dx.doi.org/10.1029/JB073i004p01127

[32] Lindner, B. and Frysinger, J.R. (2007) Bulk Atmospheric Deposition in the Charleston Harbor Watershed. Journal of Coastal Research, 23, 1452-1461. http://dx.doi.org/10.2112/05-0596.1

[33] Tsitouridou, R. and Anatolaki, C. (2007) On the Wet and Dry Deposition of Ionic Species in the Vicinity of Coal-Fired Power Plants, Northwestern Greece. Atmospheric Research, 83, 93-105. http://dx.doi.org/10.1016/j.atmosres.2006.03.005

[34] Rodhe, H., Langner, J., Gallardo, L. and Kjellström, L. (1995) Global Scale Transport of Acidifying Pollutants. Water, Air and Soil Pollution, 85, 37-50. http://dx.doi.org/10.1007/BF00483687

[35] Galloway, J.N., Townsend, A.R., Erisman, J.W., Bekunda, M., Cai, Z.C., Freney, J.R., Martinelli, L.A., Seitzinger, S.P. and Sutton, M.A. (2008) Transformation of the Nitrogen Cycle: Recent Trends, Questions, and Potential Solutions. Science, 320, 889-892. http://dx.doi.org/10.1007/BF00483687

[36] NOM-086-SEMARNAT-SENER-SCFI (2005) Specifications for Fuels in Mexico Related to Its Sulfur, Olefins and Benzene Content. Mexican Environmental Agency.

[37] Pardo, L.H., Fenn, M.E., Goodale, C.L., Geiser, L.H., Driscoll, C.T., Allen, E.B., Baron, J.S., Bobbink, R., Bowman, W.D., Clark, C.M., Emmet, B., Gillian, F.S., Greaver, T.L., Hall, S.J., Lileskov, E.A., Liu, L., Lynch, J.A., Nadelhoffer, K.J., Perakis, S.S., Robin-Abbot, M.J., Stoddard, J.L., Weathers, K.C. and Dennis, R.L. (2011) Effects of Nitrogen Deposition and Empirical Nitrogen Critical Loads for Ecoregions of the United States. Ecological Applications, 21, 3049-3082. http://dx.doi.org/10.1890/10-2341.1 